Japanere Pyohologioul Reratch

1994, Vol. 36, No, 3, 126-137

Spectal lssue : Gestate lerception

$\overline{\text { Invited Paper }}$

\title{
Gaetano Kanizsa: The scientist and the man
}

\author{
GIOVANNI BRUNO VICARIO' \\ Department of General Psychology, University of Padova, piazza Capitaniato 3, 35139 Padova, \\ Itoly
}

Theoretical position and research methods of the late Professor Gaetano Kanizsa (1913-1993) are outlined through the private recollections of the author. Some elements of history of psychology in Europe are added, with a detailed survey as to Gestalt psychology in Italy. The state of affairs in the field of event perception is examined, and a proposal to sistematically apply experimental phenomenology to event perception is set forth. Some problems of time psychology are briefly traced.

Key words: biography, Gestalt theory, event perception, history of psychology, Italy.

\section{Meinem verehrten Lehrer Herrn Professor Gaetano Kanizsa}

\section{Kanizsa, the Gestalt and I}

Some months ago I was in trouble with finding a simple way to formulate the principle that neurophysiological inquiry, although laudable for the general progress of sciences and even necessary for the treatment of cognitive diseases, is eventually useless for a true explanation of mental facts. I must add that I consider this principle as the distinguishing mark of my theoretical position among my colleagues - almost all in love with neuropsychology and computer sciences. I finally came to a satisfying lining up of arguments, and I congratulated myself on the success of the hard task. At this point I had a sudden memory flash, and I went to check upon a disregarded paper by Gaetano Kanizsa (1984), on "seeing and thinking". To my great surprise, he made the same points, and often making use of the same words. I therefore decided to literally quote

\footnotetext{
' The author, former assistant of Gaetano Kanizsa, honours the scientist and the man in outlining his theoretical positions and research methods, as they come out of the private recollections. A section on the development of Gestalt School in Italy is added.
}

him (see Vicario, 1993, pp. 204-205).

This fact made me have a deep insight into the relation between my Lehrer and me. It is rather obvious that my course of lessons in general psychology is modeled on the lessons I heard from him many times, first as a student, and then in the fifteen years I was the assistant to his chair. Since he followed the book by Egon Brunswik (1935), in reading it you can get an idea of his way to set forth the matter and the style of argumenting. Well, it is likewise obvious that I tried to ameliorate every aspect of the lessons, especially the succession of topics, that in Kanizsa appeared unorganized and accidental. I enjoyed this work of jointed restructuration and refinement for many years, but some time ago, when for the twentythird time I introduced general psychology to my students, I read in their puzzled attitude that perhaps my Lehrer was right in his way. The attempt to set forth the matter in an academic manner - first the rules, then the examples is unfruitful. The student has to be confronted with facts he can at once and directly appreciate (afterimages, optical-geometrical illusions, and so on), otherwise he cannot realize what kind of reality the psychology speaks of. Besides, they said to me that Vittorio Benussi, - the master of Cesare L. Musatti, of whom latter Kanizsa was a pupil 
- seventy years ago made use of the same technique, in a lecture hall that is just fifty meters apart from mine.

I got the same feeling with Metzger's Gesetze des Sehens (1975). Every Gestalt psychologist has his own way to explain the main phenomena of vision, and I have not been an exception to this rule. However. during the years I tried to render my exposition the most perspicuous as possible, by means of the selection of examples and of the order of arguments. I finally found that I was rewriting the book of Metzger. and that every adjustment of my topics was an approach to the form given by that author, in a way very close to the one described by $\mathrm{J}$. L. Borges in his famous short story on Menard's Don Quixote. Kanizsa and Metzger were great friends, but what amazed me was their mutual soliloquy in the common effort to understand the reasons of the way of appearance of visual objects (Why do things look as they do?). As to perceptual transparency, for instance. I never succeeded in attributing certain ideas to the first and certain ideas to the second, since they were argumenting by one voice. Examples and reasoning were common in their books, without any personal claim. It seems like Gestalt psychologists are writing the very same book. in that we discover every day that perhaps the best way to state such a thing is that of Wertheimer (1923) or that such a point was better formulated by Koffka (1962). I recently published a paper on constancy hypothesis (Vicario, 1991), and I had to admit that the core of my arguments was just a gloss on what Köhler (1913) wrote on Unbemerkte Empfindungen.

This makes me think of another aspect of Gestalt School. I can safely testify that certain phenomena described in the papers of some authors are Kanizsa's, and not because I have seen him writing the papers, or he made me notice the phenomena before the papers were conceived, but because I was acquainted with his personal interests and with the special way he used in seeing relevant phenomena where no one was capable to see anything. I never heard him claim he was the first to notice this or that effect, but his liberality in sharing the fruits of his talent was not a haughty or affected one. He simply adopted an academic style inherited, I think, from his master Musatti. The first works by Kanizsa on colour (see, e. g., 1954), as some works of other pupils of Musatti on apparent movement, are clearly the fruit of the insights of Musatti himself, but the works that gave Musatti (1924) an international renown - I refer to stereokinetic movements - are clearly indebted to the observations of Benussi (1911) himself. Curiously enough, Gestalt psychologists are a Gestalt in their own, since you will never be able to make a sure distinction between the ideas that are due to the one and the ideas that are due to the other: Everyone who is acquainted with the papers by Wertheimer, Köhler and Koffka knows very well that they constitute a unique book. In addition to, I noticed the same sort of unselfishness as to the ownership of research starting points that I can testify in the case of Kanizsa.

It happens to everybody, at a certain moment of life, to cease to pry into the future, and to turn backward in search for the past - perhaps more attractive than a future that he shall not see, and surely less disquieting. In the last two or three years I have been climbing the family tree of the Padova School of Psychology, investigating the works of Vittorio Benussi (1878-1927), the founder, and the theoretical relationship between Benussi and his master Alexius Meinong (1853-1920), the Austrian philosopher and psychologist. Higher, what Meinong inherited, about the problems of perception, from his master, Franz Brentano (1838-1917), the great opponent of Wilhelm Wundt at the time psychology was born. 
Sideways, I have been investigating what of Brentano is still living in his pupil, Carl Stumpf (1848-1936), the master of Köhler and Koffka. Downwards, what had to be the matter for the famous quarrel between Benussi (1914) and Koffka (1915; on this see also Metelli, 1987). I am still curious to know the exact reason why Musatti was a follower of his master Benussi, where Musatti's pupils, Fabio Metelli and Gaetano Kanizsa, were strong supporters of Koffka's views. Now we know that the matter at issue was the concept itself of perception, that the school of Berlin conceived as an unanalyzable process, where Benussi, still bound to the philosophical (and nominalistic, I could say) formulations of Meinong, tended to see in the process of perception both a "founding" sensory content and a "founded" phenomenal representation. Kanizsa wrote indeed a paper (1952) against the theory of a perception "as divisible in phases or stages", but in his last years, when involved in discussions and researches concerning the distinction between two supposed interlaced processes, namely "seeing" and "thinking", began to keep Benussi's views in some consideration.

I must admit to have penetrated the deep motives of Kanizsa's arguing ever too late. Take for instance his long-lasting struggle against the past experience hypothesis in the explanation of perceptual phenomena (see, for example, 1969). For a long period I held his obstinacy as a private affair, and his arguments as a public defence of Gestalt theory. Now I understand that the past experience hypothesis is the sole serious alternative choice to the Gestalt explanation of the forming of units in the perceptual field, given that Helmholtzean (cognitivistic) machinery in the brain is untenable, and Gibsonean view is just naïve realism. Therefore Kanizsa was right, in spending all his own energies into countering the sole empiristic explanation.
For another instance, take his habit to insert in the course of lectures in perception a section devoted to social psychology: That section appeared as a foreign body, perhaps more gratuitous than an excursus in animal or in genetic psychology. I knew very well his deep interest in interpersonal relations, not only because I graduated with him with a thesis on interpersonal perception, but even because during the ten-year period we shared both the laboratory and the table, he used to tell me all the academic intrigues of the faculty, lingering over a detailed description of the dynamic aspects of the behaviour of the colleagues. Besides, he was an extraordinary "psychologist": You could not hide anything to him, because he was able to discover not only those aspects of your mind you were aware of, but even those motives that were unknown even to yourself. Well, for a long period I thought that Kanizsa's excursus in social psychology, inside the course in perception was an imitation of the parallel argumenting of Köhler (1947) in his Gestalt Psychology. Many times I asked myself the reason of what seemed to me an unexplainable exception to the right way of treating perception - that is, the psychophysical one. Only many years later, after studying the main work of Lorenz (1973), I understood that behavioural world is not filled only with steady objects (like stones or trees), or with objects that move according to simple physical laws (like falling stones or flowing rivers), whose behaviour is quite predictable, but also with objects (animals, people) that are sources of self-governing behaviour, whose acting is not predictable on the basis of physical laws: They suddenly start and stop moving, without any visible cause. Hence the enormous significance of managing these events in the behavioural field for survival. Hence, also, the great weight of "social" perception, that is of the cues and the laws that allow that managing. No study 
of perception can be considered complete, if disregarding so important aspects of the behavioural world.

As it will appear later, 1 inherited no one of the research topics of Kanizsa. I was never engaged in the further promoting his most valuable achievings, like anomalous surfaces or amodal completion. He was interested in objects. I was puzzled by events. On two occasions our roads met: In a study of expressive movements (Kanizsa \& Vicario, 1970), and in a theoretical discussion of the concept of "masking" (Kanizsa \& Vicario, 1982), but these occasions were created more by the desire of finding the opportunity to collaborate, than by really common interests. In a sense, I could say that - within the limits of event perception - I have been a self-taught man. What I inherited from my Lehrer is something else. He taught me the phenomenological attitude, that is the disposition « to simply accept the facing thing as it is... to let the thing speak for its own, without indulging in what we know, or we previously learned, or in what is obvious, in the knowledge of the subject, in logical demands, in linguistic prejudices... $»$ and so on (Metzger, 1963, p. 12).

It is a curious thing, phenomenology. You cannot learn it on books: You have to stay side by side with somebody who is a phenomenologist. In our case, the training I received was made of repeated observations and small and sensible handmade variations of stimuli, accompanied by a continuous overt muttering that uncovered the paths of thinking. Every year I became more and more aware of the value of the gift I got. It makes me manage perceptual problems, individuate the variables of a phenomenon, think of the lines of an experimental setting, sketch a tentative explanation. But that is only routine. My Lehrer rendered me member of a School, he put me in touch with Benussi, Husserl, Brentano, he made me participate in a now secular enterprise, that is the explanation of our sensory experience. No matter whether one is up to those men: The enterprise is sufficiently big to guarantee the repayment to every member of the rope.

Concerning sensory experience, it has always been clear to me that students of perception are people of two kinds. On the one hand you have men interested in describing the world outside of us, like phenomenologists and psychophysicists: Their problem is why things are so and so, and not otherwise. On the other hand you have men interested in what happens inside the brain or the mind, like cognitivists: Their problem is the way information is processed in order to give that picture of external world we know. Of course Kanizsa was a perceptionist of the first kind, since he was extremely curious about the fine structure of objects and forever amazed by the features he was able to discover. With much yearning I remember some long walks through the Carso highland, in the first days of November, during which he lingered to show me the red leaves of sumachs, or the branch interlacements of the already stripped trees, or even the embroideries that the rain-water had hollowed in the tender calcareous rocks. In his oil paintings - Kanizsa was a quite estimated artist - his interest was more addressed to the microstructure of the painted surfaces, crowded by a multitude of repeated tiny brush strokes, than to the whole composition, that appeared as an abstract representation. I always considered his way of painting as highly revealing of his renowned ability to look into the nature of things - he claimed he was a "thingologist" - assuming that phenomenological attitude so well described by Metzger (1963, p. 12): «To stand before the thing with reverence and love, if anything reserving our doubt and mistrust for the premises and concepts we so far used to understand the world of data".

Yes, the data. Gaetano Kanizsa was a cit- 
izen of a cosmopolitan town (Trieste), and was born in a cosmopolitan family (his father was Hungarian, his mother Slovenian): His attitude toward life and the world was always one of smiling scepticism, which he transfused in his scientific enterprise. I always appreciated his theoretical minimalism, cause or effect of his exclusive attention for the data of immediate experience. (Respect for data and theoretical minimalism that he shared with another eminent psychologist from Trieste, Vittorio Benussi.) I saw Kanizsa always attentive to single perceptual phenomena, and in some way careless of their theoretical arrangement. He was a Gestaltist, I think, because he was an experimental phenomenologist, but during the years I saw him abandon the cumbersome physiological hypotheses of Köhler and Koffka, and retire to his own view of pure phenomena bounded by phenomenal laws. I am sufficiently old to have seen the rise and fall of a couple of celebrated theories and of a lot of explicative models. When I press my students for being suspicious of theories and sticking to facts, I feel myself as the very pupil of my sehrverehrten Lehrer.

\section{Gestalt School in Italy}

Dem Andenken Max Wertheimers und den italienischen und japanischen Freunden, in denen sein Geist lebendig geblieben ist [In memory of Max Wertheimer, and of Italian and Japanese friends, in which his spirit is still alive]. With these words begin the Metzger's Gesetze des Sehens, (1975, third edition), the greatest monument ever erected to the science of vision. To vision, not to psychophysics, psychophysiology or neuroscience of vision. To vision intended as immediate experience, mental fact, subject matter of psychology.

I am too poor a connoisseur of the history of Psychology to tell what the Wertheimer's "spirit" consisted of. The tangle of ideas from which Gestalt theory emerged, at the dawn of the century, is far beyond my ability to unravel it. Wertheimer had been pupil of Christian von Ehrenfels in Praha, of Carl Stumpf in Berlin and of Friedrich Schumann in Frankfurt (Sarris, 1987): That should mean that he was a follower of Brentano's phenomenology. According to Thinès (1977), the neurophysiological hypotheses (isomorphism) with which Wertheimer and Köhler stuffed phenomenal evidence represent a backward step in the evolution of phenomenology, consequent to Husserl's abandonment of the psychological scene, while the forward step is recognizable in the Austrian School (Meinong and Benussi). Anyway, I think that, when speaking of the "spirit of Wertheimer", Metzger refers to the commandment that Husserl synthesized in the phrase: Zurück zu den Sachen selbst! [Back to the things themselves!], that first imposes a careful inspection of facts, and then makes us understand that the explanation of facts may be found in the visible structures of facts themselves. In short, phenomenology, and experimental, if possible. Exactly what Kanizsa did along his whole scientific life.

At this point, I think that some Japanese researchers - that in the mind of Metzger share with some Italian colleagues the privilege to get ahead with the spirit of Wertheimer and of Kanizsa - would enjoy a brief account on the men and works that still justify Metzger's statement.

After Fabio Metelli (1908-1987) and Gaetano Kanizsa (1913-1993), the most influential representative of the phenomenological school in Italy is now Paolo Bozzi, at the University of Trieste. Former assistant of Kanizsa, he is renown for his enquiries in the so-called naïve physics, a topic that he opened more than thirty years ago, and that was discovered by North American psychol- 
ogists quite recently. Of most important value two studies: the first on the genesis of unification principles. the second on a new observational technique, that Bozzi calls "interobservative", both testifying his epistemological and methodological talent. Bozzi (1989) has collected the above mentioned researches and other studies in a book, significantly entitled Fenomenologia sperimentale [Experimental phenomenology]. Riccardo Luccio, who shared with Kanizsa the Wolfgang Metzger Preis in 1986, with a paper on the disputed argument of Höffding (see Kanizsa and Luccio, 1987), also lectures in Trieste; see also his paper on Gestalt problems migrated in contemporary cognitive psychology (Luccio, 1989). In Trieste we have also Walter Gerbino, the last assistant of Kanizsa, of whom I tell nothing, since he writes on this same issue of the journal. Giorgio Tampieri, who is now lecturing child psychology, has been assistant of both Kanizsa and Metelli: His most remarkable research in perception concerns the tridimensionality of objects originated by stereokinetic effect (Tampieri, 1956).

Padova has been the seat of Benussi, Musatti and Metelli (there Kanizsa graduated in Philosophy), so there we find quite a few phenomenologically oriented psychologists In Padova Mario Zanforlin lectures in animal and comparative psychology. He is perhaps the most "Gestaltist" of all us, as his master Metelli was regarded as the most uncompromising keeper of the Gestalt orthodoxy. The main contributions of Zanforlin concern stereokinetic effects (like Benussi and Musatti) and above all the perception of Gestalten in chicks (Zanforlin, 1988; Vallortigara, Zanforlin, \& Compostella, 1990). In Padova also lectures Guido Petter, the first assistant of Kanizsa and now the most renowned child psychologist in Italy (in the Piagetian tradition). At the times he worked in perception, he attained outstanding results in the study of the phenomenal scission within one monochromatic surface, when scission gives rise to two figures separated in depth (Petter, 1956). Kanizsa's work on anomalous surfaces has developed into the researches of Marco Sambin (see, e. g., 1987), and the experimental phenomenology of colours - another chief interest of Kanizsa - is carried on by Osvaldo Da Pos (see, e. g., 1991). Gestalt-oriented researchers and theorists of psychophysical measurement, interested in the assessment of experimental phenomenology, are Sergio Cesare Masin (see the book he recently edited, 1993) and Luigi Burigana (see, e. g., 1994). Manfredo Massironi, now in Verona, mainly a student of pictorial perception, wrote a remarkable paper on the perception of folding (1988).

The Gestalt School had some influence even in Bologna. Metzger, in his periodical round trips to Italy, used to add Bologna to Padova and Trieste, and in every place he was informed of the current research. We paid very much attention to his advice, and I do not remember whether Kanizsa or Metelli used to say that they did not teach psychology, but "metzgerology". In Bologna Renzo Canestrari carried out his researches on the rotating window (Canestrari and Farnè, 1969, in opposition to Ames' theorizing), and Gian Franco Minguzzi (1968) experimentally tested Michotte's hypotheses on "ampliation of movement" with researches on the perception of "braked movement" and of "waiting". I think that the last echoes of Gestalt-oriented enquiries can be found in some works of Mario Farnè (e. g., 1977) and of Luciano Stegagno, now in Padova (see, e. g., Stadler, Stegagno, and Trombini, 1979). To the Bologna group belongs Giuseppe Galli, now lecturing in Macerata, whose main contributions are on the structure and dynamics of the phenomenic I (see, e. g., 1973).

If one desires to be informed about the fortunes of Gestalt School in Italy, he can 
resort to the books of Kanizsa and Legrenzi (1978) and of Kanizsa and Caramelli (1988), that demonstrate the central position of Kanizsa in the debate about general theories of perception and of psychology. For the same purpose the Festschrift for Kanizsa edited by Gerbino (1984) and the Festschrift for Metelli edited by Flores d'Arcais (1975) are most useful.

I will close this section by recalling the Conference on processes of perceptual organization, held in Abano in June 1979, where Jacob Beck (1982) and Fabio Metelli gathered the most influential researcher in perception-like F. Attneave, J. J. Gibson, J. Hochberg, E. Leeuwenberg. N. Pastore, F. Restle and Kanizsa himself. I think that Metelli was looking forward a cross-fertilization of schools of psychology that ignore each other, but the conference soon revealed as a confrontation between information-processing theories and Gestalt-oriented phenomenology. From another point of view, a confrontation between people who owned all the tools for the mathematical demonstration of anything. with no idea on what apply the tools to, and people who knew very well what were the things to be investigated, but with no idea about which tools were to be employed for reaching any else demonstration. The match drew, and everybody remained of his own mind. I saw Kanizsa shaking his head, and I began to think that every age has his Wundt and his Brentano: the two halves of a psychological truth that you cannot put together.

\section{A Gestalt Look into Psychological Time}

As for myself, I started with researches on perception of events. In the acoustic field I investigated the tunnel effect, phenomenal dependence, temporal displacement, perceptual streaming and so on (for a brief account, see Beck 1982, pp. 269-283); in the visual field 1 investigated various types of movement, finding also a counterpart of auditory streaming in stroboscopic movements (Vicario, 1965). In fact, my interest was toward psychological time (and in that sort of enquiries I also met Japanese researchers, like Abe, 1935, or Suto, 1941), but at the end of these investigations $I$ realized that $I$ was not ready for studying the relations between perception of events and psychological time (see Vicario, 1973), and I abandoned the field. A lucky research on an unknown effect in visual acuity (1971) cast me on the terrain of optical-geometrical illusions (see, e. g., 1978 ) and of general vision, where I remained till a few years ago: It is hard to imagine more frustrating subject - as to theoretical principles - than illusions, but at least I got a deeper insight of the mechanism of phenomenological explanations. In the meantime new technologies have been developed (faster microprocessors, better video graphic adapters, a lot of software) that allowed me to translate the problems I have investigated in the auditory domain to the visual one. So I returned to the perception of events, namely to the perception of order in successions of very brief stimuli presented in overprinting (Vicario, 1992). At present I am engaged on two fronts: a better knowledge of the method of successive comparison (e. g., Vicario, Vidotto, \& Tomat, 1994), the unique psychophysical procedure suitable for the study of events (Vicario 1994) and the investigation of particular phenomena, like the perception of continuous becoming (Vicario \& Zambianchi, 1994a) or the perception of durableness (as opposite to instantaneity, see Vicario and Zambianchi, 1994b). At the same time I have been forced to carefully consider the studies of Brentano (Kraus, 1930; see also Volpi, 1987) and Husserl (Boehm, 1966) on the forming of conscience of time, since I convinced myself that the present way to treat the problems of psycho- 
logical time (e. g.. Michon \& Jackson 1985; Block, 1990) is hopelessly missing the target.

I am longing for a study of events that can renew the successes of Gestalt theory of perception in the study of objects. Some invaluable insights and experiments of Michotte (e. g.. 1962, 1963) persuaded me that a phenomenological approach in the investigation of the forming of events in the perceptual field is possible, and in some cases unavoidable. At this point the experience matured under the mastership of Kanizsa comes in handy: His arguing on some general features of the ways of appearing of objects (transparence, masking, phenomenal scission of homogeneous chromatic surfaces, amodal completion, and so on) are for me the guiding lines for seeing something rational in the transformation of the unceasing flow of the stimuli - anonymous and unrelated ones - in the harmonious and sensible perceived becoming. In a way, there remains to do in the field of events what Wertheimer already did for objects: to work out the principles of forming of events themselves, to begin with their longitudinal separation (e. g., as in articulation of melodies and in grouping of rhythms, as in the passage from changing to substitution, see Michotte, 1962) and their vertical separation (e. g., as in auditory figure-ground effects, as in hierarchical organization of coexistent movements, see Johansson, 1978).

Surely, we move in a theoretical void. To begin with, we lack a satisfactory definition of "event": The students of the field fluctuate from the "bicategorial" view (objects and events are of different species: common sense, Ingarden, 1935) to the "monocategorial" view (objects are a subspecies of events, or events are a subspecies of objects, see Whitehead, 1929, Kotarbinski, 1955; see also Smith and Casati, 1993). In the second place, there is the problem of the perception of continuous becoming: We have a maxi- mum of literature on movement in space, but almost nothing on movement in quality (change). Indeed, nobody seems to realize that current theories of perception cannot account for the perception of continuity of change, given that sensory registers are conceived as still storages of data, no matter if for 10 or $100 \mathrm{~ms}$; similarly, no student of memory seems to realize that the "traces" of events are by no means events in themselves, in so rendering incomprehensible the simple task of successive comparison of two events, the one flowing under our eyes and the other "crystallized" in the maze of long term memory. Last but not least, no student of perception of duration seems to consider the fact that the act of perception of a duration goes on like the object of the act itself: No wonder that the field of perception and estimation of duration is a cemetery of contradictory data (see, e. g., Fraisse, 1984, or Zakay, 1990, who speaks of the "evasive art of subjective time measurement").

There is no need to point out that such problems are not unfamiliar to old psychological literature (see, e. g., Brentano in Kraus, 1930; Husserl in Boehm, 1966; Stern, 1897, or even Benussi, 1913). Valuable suggestions could come from Minkowski (1968), and I suspect that even in Janet (1928) we could find key reflections on the building up of psychological present. I hope that such valuable thoughts will be carefully examined in detail, in order to see whether they are open to experimental proofs. This is the future of time psychology, given that its flattening to the time of mechanics proves to be unsuccessful.

In general, I think that the problem of psychological time is too big to be confronted as a whole: It is like a watermelon at which we cannot make a snap. But even a watermelon can be eaten, cutting it into slices. And so the manifold mystery of external and internal becoming can be attacked by 
means of particular experimental investigations, of which the perception of events is an example. With much amusement I remember the friendly quarrel between Musatti and Kanizsa about the role of past experience in present experience. Musatti (1964), always trusting the power of logical thought, maintained that an experiment that verifies or falsifies that role was impossible, since we are not able to manipulate the two variables in play: We needed either to change the physical laws of our world, or to change the rules of the perceptual apparatus of the observer. Kanizsa (1969), always trusting the power of facts, answered back that perhaps it was so, but that it was better to try. In this way he found convincing proofs that not only past experience has little to do with present perceptual experience, but even that the supposedly "impossible" experiment was a practicable one.

\section{Epilogue}

The day of the official retirement of Gaetano Kanizsa (in the autumn of 1983), in the main lecture hall of the "Old University" in Trieste a crowded ceremony took place, during which the pupils of Kanizsa - from the oldest one, Renzo Canestrari, nearly of the same age - alternated on cathedra for the so-called laudatio. The ceremony met with academic lustre and success, in part because of the presence of Cesare L. Musatti, then aged 84 , the dean of Italian psychologists the man who introduced in Italy both the Gestaltheorie and the psychoanalysis of Freud - who silent sat in the first row. After the ceremony the people dispersed, but in the evening the intimate friends (about fifty!) met in a restaurant on Carso highland for a less pompous and more cheerful leave. Everything went on as usual, till the end of the dinner. At once, the old man Musatti, the Master of everybody in the room, stood up and began to speak. In half an hour, in front of us, he poured out the whole inside story of Italian psychology, the one weaved by the men who trusted the new scientific discipline. Every character of that history got his own blame or praise; as to Kanizsa, Musatti at first teased his juvenile private and public intemperances, and then emphasized every aspect of his success: scientific creativity, academic management and human popularity. At the end of the speech I poked Canestrari in the ribs, and made him notice the exceptionality of the event. It often happens, for a retiring professor, to hear the praises of his pupils, but it took to be Kanizsa, to hear the praises from his own master!

After his retirement Kanizsa continued to be working and creative, in so benefiting his friends and pupils: Many times I have gone to him in order to get some advice in the treatment of perceptual phenomena or of theoretical problems. Gaetano Kanizsa got very much from life, and especially the last gift: to avoid the old age (unbearable and shameless, says Homer, llias), of which he was afraid more than of any other thing. I am not so sad about his death: His papers and books speak for him, and until we shall carry on his scientific purpose, he will be alive. The trouble with men that passed away is however that they continue to speak, but when questioned they answer no more.

\section{References}

Abe, S. 1935 Experimental study on the co-relation between space and time. Tohoku Psychologica Folia, 3, 53-68.

Beck, J. (Ed.) 1982 Organization and representation in perception. Hillsdale, N. J.: Lawrence Erlbaum Associates.

Benussi, V. 1911 Über die Motive der Scheinkörperlichkeit bei umkehrbaren Zeichnungen. Archiv für die gesamte Psychologie, 20, 363-396.

Benussi, V. 1913 Psychologie der Zeitauffassung. 
Heidelberg: Winter.

Benussi, V. 1914 Review of the paper of K. Koffka and F. Kenkel: Beiträge zur Psychologie der Gestalt- und Bewegungserlebnisse, Zeitschrift für Psychologie, 67, 353-449. Archi fiur die gesamte Psychologie. 32, 50-57.

Block, R. A. (Ed.) 1990 Cognitive models of psychological time. Hillsdale. N. J.: Lawrence Eribaum Associates.

Boehm, R. (Ed.) 1966 Husserliana. Bd. X. Zur Phänomenologie des inneren Zeitbewußtsein. The Hague: Nijhoff.

Brunswick. E. 1935 Experimentelle Psychologie in Demonstrationen. Wien: Julius Springer.

Bozzi, P. 1989 Fenomenologia sperimentale [Experimental phenomenology]. Bologna: II Mulino.

Burigana, L. 1994 Le interrelazioni percettive secondo W. C. Gogel. Esposizione di un modello determinativo della percezione [Perceptual interrelations in W. C. Gogel's works. Description of a determinative model of perception]. Rivista di Psicologia. (In press)

Canestrari, R., \& Famè, M. 1969 Depth cues and apparent oscillatory motion. Perceptual and Motor Skills, 29, 508-510.

Da Pos, O. 1991 Trasparenze [An essay on transparency]. Milano: Icone.

Farnè, M. 1977 Brightness as an indicator to distance: relative brightness per se or contrast with the background? Perception, 6, 287-293.

Fraisse, P. 1984 Perception and estimation of time. Annual Review of Psychology, 35, 1-36.

Flores d'Arcais, G. B. (Ed.) 1975 Studies in perception. Festschrift for Fabio Metelli. Milano: Martello-Giunti.

Galli, G. 1973 Methodologische Grundsätze zur Erforschung des phänomenalen Ich. Psychologische Beiträge, 15, 550-574.

Gerbino, W. (Ed.) 1984 Conoscenza e struttura [Knowledge and structure]. Bologna: Il Mulino.

Ingarden, R. 1935 Von formalen Aufbau des individuellen Gegestandes. Studia Philosophica, 1, 29-106.

Janet, P. 1928 L'évolution de le memoire et de la notion du temps. Paris: Maloine.

Johansson, G. 1978 Visual event perception. In R. Held, H. W. Leibowitz \& H-L. Teuber (Eds.), Perception. Handbook of sensory Physiology. Vol. VIII. Berlin: Springer. Pp. 675-711.

Kanizsa, G. 1952 Legittimità di una analisi del processo percettivo fondata su una distinzione in "fasi o stadi" [Legitimacy of the analysis of per- ceptual process when grounded on the distinction of "phases" or "stages"). Archivio di Psicologia, Neurologia e Psichiatria, 13, 292-323.

Kanizsa, G. 1954 Alcune osservazioni sull'effetio Musatti [Some observations on Musati's effect]. Archivio di Psicologia, Neurologia e Psichiatria, 15, 265- 271 .

Kanizsa, G. 1969 Perception, past experience and the "impossible experiment". Acta Psychologica, 31, 66-96.

Kanizsa, G. 1984 Vedere e pensare [Seeing and thinking]. Ricerche di Psicologia, 8, 7-42.

Kanizsa, G., \& Caramelli, 1988 L'eredità della psicologia della Gestalt [The heritage of Gestalt Psychology]. Bologna: Il Mulino.

Kanizsa, G., \& Legrenzi, P. (Eds.) 1978 Psicologia della gestalt e psicologia cognitivista [Gestalt psychology and congnitivistic psychology]. Bologna: Il Mulino.

Kanizsa, G, \& Luccio, R. 1987 Formation and categorization of visual objects: Höffding's never confuted but always forgotten argument. Gestalt Theory, $9111-127$.

Kanizsa, G., \& Vicario, G. 1970 La perception de la réaction intentionnelle. Bulletin de Psychologie, 23, 1019-1039.

Kanizsa, G., \& Vicario, G. 1982 Sul mascheramento visivo [On masking in visual field]. Report n. 57 dell'Istituto di Psicologia dell'Università di Padova. Padova: CLEUP.

Koffka, K. 1915 Zur Grundlegung der Wahmehmungspsychologie. Eine Auseinandersetzung mit V. Benussi. Zeitschrift für Psychologie, 73, 11- 90.

Koffka, K. 1962 Principles of gestalt psychology. London: Harcourt Brace.

Köhler, W. 1913 Über unbemerkte Empfindungen und Urteilstäuschungen. Zeitschrift für Psychologie, 66, 51-80.

Köhler, W. 1947 Gestalt psychology. New York: Liveright.

Kotarbinski, T. 1955 The fundamental ideas of pansomatism. Mind, 64, 488-500.

Kraus, O. 1930 Zur Phänomenognosie des Zeitbewuß tsein. Archiv für die gesamte Psychologie, 75, 1-22.

Lorenz, K. 1973 Die Rückseite des Spiegels. München: Piper \& Co.

Luccio, R. 1989 Gestalt problems in cognitive psychology: field theory, invariance and auto-organisation. In V. Roberto (Ed.), Intelligent perceptual systems. Berlin: Springer. Pp. 2-19.

Masin, S. C. (Ed.) 1993 Foundations of perceptual theory. Amsterdam: North-Holland. 
Massironi, M. 1988 A new visual problem: phenomenic folding. Perception, 17, 681-694.

Metelli, F. 1987 La polemica Benussi-Koffka [The Benussi-Koffka controversy]. In G. Mucciarelli (Ed.), Vittorio Benussi nella storia della psicologia inaliana [Vittorio Benussi in the history of Italian psychology]. Bologna: Pitagora. Pp. 119145.

Metzger,W. 1963 Psychologie. Darmstadt: Steinkopff.

Metzger, W. 1975 Gesetze des Sehens. Frankfurt am Main: Kramer.

Michon, J. A., \& Jackson, J. L. (Eds.) 1985 Time, mind, and behavior. Berlin: Springer.

Michotte, A. 1962 A propos de la permanence phénoménale: faits et theories. In A. Michotte, et collaborateurs (Eds.), Causalité, permanence et réalité phénoménales. Paris: Béatrice-Nauwelaerts. Pp. 347-371.

Michotte, A. 1963 The perception of causality. London: Methuen

Minguzzi, G. F. 1968 Sulla validità della distinzione fra percezione di nessi causali e percezione di dipendenze funzionali [On the validity of the distinction between perception of causal connections and perception of functional dependences] In G. Kanizsa \& G. Vicario (Eds.), Ricerche sperimentali sulla percezione [Experimental researches on perception]. Trieste: Universita di Trieste.

Minkowski, E. 1968 Le temps vecu [Italian edition: Il tempo vissuto. Torino: Einaudi 1971]

Musatti, C. L. 1924 Sui "fenomeni stereocineticl" [On "stereokinetic phenomena"]. Archivio italiano di Psicologia, 3, 105-120.

Musatti, C. L. 1964 Struttura ed esperienza nella fenomenologia percettiva [Structure and experience in the phenomenology of perception]. In C. L. Musatti (Ed.), Condizioni dell'esperienza e fondazione della psicologia [Conditions of experience and foundations of psychology]. Firenze: Editrice Universitaria. Pp. 351-367.

Petter, G. 1956 Nuove ricerche sulla totalizzazione percettiva [New enquiries on perceptual totalization]. Rivista di Psicologia, 50, 227-231.

Sambin, M. 1987 A dynamic model of anomalous figures. In S. Petry \& G. E. Meyer (Eds.), The perception of illusory contours. New York: Springer. Pp. 131-142.

Sarris, V. (Ed.) 1987 Max Wertheimer in Frankfurt. Frankfurt am Main: Johann Wolfgang Goethe Universität.

Smith, B., \& Casati, R. 1993 Naive physics: an essay in ontology. Philosophical Psychology. (In press)

Stadler, M., Stegano, L., \& Trombini, G. 1979 Quantitative Analyse der Rauschschen Prägnanzaspekte. Gestalt Theory, 1, 39-51.

Stern, W. 1897 Psychische Präsenzzeit. Zeitschrift fuir Psychologie and Physiologie der Sinnesorgane, 13, 325-349.

Suto, Y. 1941 On the effect of phenomenal distance upon time perception. Japanese Journal of Psychology, 16, 95-115.

Tampieri, G, 1956 Contributo sperimentale all'analisi dei fenomeni stereocinetici [Experimental contribution to the analysis of stereokinetic phenomena]. Rivista di Psicologia, 50, 1-10.

Thinès, G. 1977 Phenomenology and the science of behaviour. London: Allen \& Unwin.

Vallortigara, G., Zanforlin, M., \& Compostella, S. 1990 Perceptual organization in animal learning: cues or objects? Ethology, 8, 89-102.

Vicario, G. 1965 Vicinanza spaziale e vicinanza temporale nella segregazione degli eventi [Spatial and temporal proximity in the mutual segregation of events]. Rivista di Psicologia, 59, 843-863.

Vicario, G. 1971 Visual acuity and stimulus area. Psychologische Forschung, 35, 17-26.

Vicario, G. 1973 Tempo psicologico ed eventi [Psychological time and events]. Firenze: Giunti-Barbèra.

Vicario, G. 1978 Another optical-geometrical illusion. Perception, 7, 225-228.

Vicario, G. B. 1991 L'ipotesi della costanza in psicologia [The constancy hypothesis in psychology]. Rivista di Psicologia, 76, 9-18.

Vicario, G. B. 1992 Osservazioni sperimentali sulla percezione di sequenze di stimoli visivi molto brevi presentati in overprinting [Experimenta] observations on the perception of sequences of very brief visual stimuli given in overprinting]. Rivista di Psicologia, 77, 7-20.

Vicario, G. B. 1993 On experimental phenomenology. In S. C. Masin (Ed.), Foundations of perceptwal theory. Amsterdam: North-Holland. Pp. 197-219.

Vicario, G. B. 1994 Considerazioni di metodo nello studio della percezione degli eventi [Methodological consideration in the study of perception of events]. Manuscript submitted to Ricerche di Psicologia.

Vicario, G. B., Vidotto, G., \& Tomat, L. 1994 Valutazione della lunghezza di linee esposte stabilmente $o$ in evoluzione: dati e problemi 
[Estimation of length for static and evolving lines: data and problems]. Ricerche di Psicologia. (In press)

Vicano, G. B., \& Zambianchi, E. 1994a Valutazione dei livelli iniziali e terminali di chiarezza in eventi visivi in evoluzione [Estimation of initial and final brightness in visual evolutionary events]. In preparation.

Vicario, G. B., \& Zambianchi, E. 1994b Soglia della durevolezza per stimoli visivi acromatici [Durableness threshold for achromatic visual stimuli]. In preparation.

Volpi, F. 1987 Il problema della coscienza del tempo in Brentano [The problem of conscience of time in Brentano]. In G. Mucciarelli (Ed.),
Vittorio Benussi nella storia della psicologia italiana. Bologna: Pitagora. Pp. 65-104.

Wertheimer, M. 1923 Untersuchungen zur Lehre von der Gestalt, II. Psychologische Forschung, 4. $301-350$.

Whitehead, A. N. 1929 Process and reality. An essay in cosmology. New York: Macmillan.

Zakay, D. 1990 The evasive art of subjective time measurement: some methodological dilemmas. In R. A. Block (Ed.), Cognitive models of psychological time. Hillsdale, N. J,: Lawrence Erlbaum Associates. Pp. 59-84.

Zanforlin, M. 1988 Stereokinetic phenomena as good Gestalts. Ge'stalt Theory, 10, 187-214.

(Received March 8, 1994; accepted May 7, 1994) 